\title{
The Role of Intangible Resources for Waqf in Higher Education: A Conceptual Review
}

\author{
Wan Rasyidah Wan Musa, Mohamed Saladin Abdul Rasool, Siti Sara \\ Ibrahim
}

To Link this Article: http://dx.doi.org/10.6007/IJARBSS/v11-i10/11512

DOI:10.6007/IJARBSS/v11-i10/11512

Received: 15 August 2021, Revised: 19 September 2021, Accepted: 30 September 2021

Published Online: 21 October 2021

In-Text Citation: (Musa et al., 2021)

To Cite this Article: Musa, W. R. W., Rasool, M. S. A., \& Ibrahim, S. S. (2021). The Role of Intangible Resources for Waqf in Higher Education: A Conceptual Review. International Journal of Academic Research in Business and Social Sciences, 11(10), $1307-1315$.

\section{Copyright: (c) 2021 The Author(s)}

Published by Human Resource Management Academic Research Society (www.hrmars.com)

This article is published under the Creative Commons Attribution (CC BY 4.0) license. Anyone may reproduce, distribute, translate and create derivative works of this article (for both commercial and non-commercial purposes), subject to full attribution to the original publication and authors. The full terms of this license may be seen at: http://creativecommons.org/licences/by/4.0/legalcode

Vol. 11, No. 10, 2021, Pg. 1307 - 1315

Full Terms \& Conditions of access and use can be found at http://hrmars.com/index.php/pages/detail/publication-ethics 


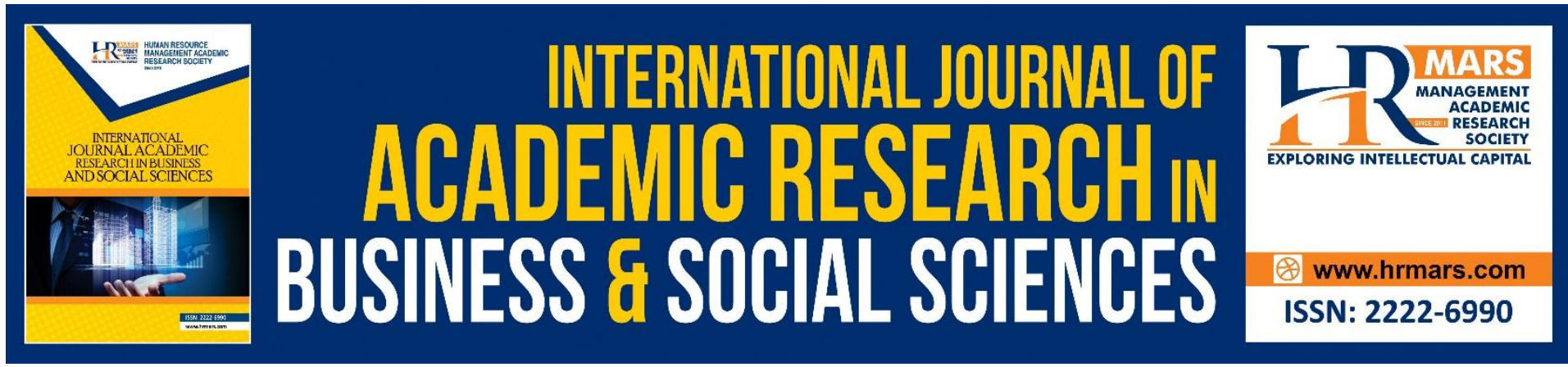

\title{
The Role of Intangible Resources for Waqf in Higher Education: A Conceptual Review
}

\author{
Wan Rasyidah Wan Musa, Mohamed Saladin Abdul Rasool \\ Faculty of Business and Management, Center for Islamic Philanthropy and Social Finance \\ Universiti Teknologi MARA, Cawangan Melaka, Malaysia
}

\begin{abstract}
Siti Sara Ibrahim
Faculty of Business and Management, Universiti Teknologi MARA, Cawangan Negeri Sembilan, Kampus Rembau, Malaysia, Center for Islamic Philanthropy and Social Finance Universiti Teknologi MARA, Cawangan Melaka, Malaysia
\end{abstract}

\begin{abstract}
Waqf as one of the sources of Islamic economic system has historically made significant contributions to educational institutions in Egypt, Turkey, and Saudi Arabia. Waqf has also made a significant contribution in Malaysia, with many public universities demonstrating progress in waqf higher education setting. The desire of the community to contribute and sustain the availability of the necessary resources have made this possible. The rising expenses over the next decade in delivering a higher quality education has increased the government spending on higher education, which require all public and private universities to become more independent and develop their own funding strategies to ease the burden caused by economics depreciation. To access to financial funding, waqf in higher education must first adhere to its intangible resources to encourage public desire to contribute to waqf education fund and operational setting. The current study aims to conceptually examine how intangible resources influence waqif's willingness to contribute to the waqf education fund. The role of intangible resources in Resource Based View (RBV) theory is extracted to emphasis factors that influence the willingness to contribute in waqf education setting. The RBV previously is primarily concerned with the resources and competencies that give an organisation a competitive advantage and influence its performance. However, the current study concentrates on intangible assets from the perspective of an individual. Thus, the resources in RBV theory used in this study has defined human performance in terms of commitment and trust. It is then translated into a finding using a research framework, leading to hypothesis testing and be extremely useful in guiding future empirical research.

Keywords: Intangible Resources, Waqf Higher Education, Theory of Planned Behaviour, Resource Based View (RBV) Theory, Willingness in Waqf Contribution
\end{abstract}

\section{Introduction}

Education has become one of the critical components for Malaysia to achieve the goal of becoming a developed nation (Adnan \& Valliappan, 2019). Indeed, the government is also 
aware of the importance of education in this regard and has thus implemented various relevant policies and enforced the internal education system to bridge the gap between Malaysia and other developed nations (Rauf \& Jabeen, 2019). However, as the government spending on higher education has increased, it requires all public and private universities to be more independent and develop their own funding strategies to alleviate the burden on the Malaysian government caused by economic depreciation. In fact, Nurjannah and Abdullah (2020) in their study also mentioned that the unstable Malaysian economic condition between 2018 and 2020 had highlighted the need of waqf as an effective and feasible form of financial resources.

Waqf has the potential to contribute to the development of higher education and support any additional educational financing requirements. In fact, waqf for education has a long history of demonstrating strong ties to socio-economic development (Mahamood et al., 2018). It is shown from the best example of waqf-funded educational institution, the University of Al-Azhar and following to the other in the West that are operating using the same concept under the term "endowment" like the University of Harvard, University of Oxford and University of Cambridge. Early example of waqf for education in Malaysia includes the donation of ulama' for pondok institutions' sustainability and survival that primarily involved in the teaching and learning of the Qur'an and hadiths (Ahmad et al., 2019;2018).

Meanwhile, the Malaysia Education Blueprint (2015-2025) drives the implementation of a new incentive which accelerates the establishment of an endowment or waqf system for both public and private higher education institutions. In fact, public universities have been regularly tracking this initiative since every higher education institutions (HEls) would require sustainable sources of income to fund their operating costs. Besides, the beauty of waqf education is found when it can be used to fund the construction of hostels, the provision of scholarships and allowances, and the creation of educational materials (Mujani et al., 2018). As a result, many other Malaysian public universities became interested in the concept of waqf for education and started to establish their own Islamic endowment fund or waqf fund (Bakar et al., 2019).

However, waqf for education in Malaysia is still in its early stages as it requires the institutions to firstly determine the key resources to be adhered before an institution can implement the concept and transform itself into an income generation ecosystem (Mujani \& Yaakub, 2017; Bakar 2018; Hasan et al., 2019; Bakar et al., 2019). There are several challenges faces during the implementation waqf concept in higher education institutions, for example waqif / endower is somehow holding back from making repeat contributions to waqf funds, the lack of awareness and understanding of waqf among public, including university staff, students, as well as administrators of waqf institutions (Ali \& Markom, 2020; Razak et al., 2018).

Hence, this current study aims to conceptually examine how intangible resources (trust and commitment) can drive the willingness of people to contribute to waqf for higher education purposes, which will in turn provide long-term benefits for numerous stakeholders including students, researchers, and institutional staff. This is to address knowledge gap when previous studies have mostly focused on tangible resources and viewed from organisation's perspective of resources. RBV theory is employed to identify the individual resources of institutional members that are crucial for increasing their willingness to contribute to waqf. 


\section{Literature Review \\ Development of Waqf Higher Education}

A waqf is an endowment (donation) made by a Muslim under Islamic Law to a fund manager (mutawali/nazhir), who is responsible for generating profits that are subsequently used to support socioeconomic development. A waqf is like an endowment fund but is strongly encouraged in Islam as a contribution to society (Sukmana, 2020). Until the present moment, waqf institution keep on flourish throughout the whole world as at Turkey for an example, which has come out with 142 waqf universities and the numbers continues escalating (Mujani \& Taib, 2017; Asni et al., 2020). Correspondingly, Al-Azhar university, which is the world's oldest university was built and continues providing free education from the elementary till the tertiary level (Hashim, 1990; Mujani \& Yaakub, 2017). Despite that, there are numbers of universities advantages from the waqf, for instance the University of Al-Qurawiyin in Fez, Morroco, the University of Al-Muntasiriyah in Iraq, the University of Qurtubah in Spain, The King Abdul Aziz University in UAe and the Islamic University of Indonesia in Yogyakarta, Indonesia (Asni et al., 2020; Usman \& Ab Rahman, 2020).

Waqf education in Malaysia is manifested in various forms, such as scholarships, financial and student dormitory buildings, as well as learning tools, such as tables and books (Latiff et al., 2006). This development is important because this study found that funding education through waqf implementation able to reduce the problem of children from dropping out and those who cannot continue their studies due to poverty (Mustaffa \& Muda, 2014). The concept of waqf for developing public education is well known in this country (Ibrahim et al., 2013; Ismail et al., 2015; Sari et al., 2018) and the proof is found in the variety of teaching huts that sit like mushrooms in Malaysia's north, such as in Kedah, Pinang, and the Perak islands, which mostly concentrate on the low and middle levels of education (Aziz \& Johari, 2014).

The contributions of waqf in developing societies through education are well recorded throughout history. Specific to public universities in Malaysia, this institution has shown their interest to develop higher education by establishing a waqf centre after they realise the significant contribution of waqf toward sustainable and survival of higher education. Table 1 below highlights among the public universities in Malaysia that has successfully set-up their own waqf administration for education purposes. 
Table 1. List of Waqf Administration Institution in Higher Education in Malaysia

\begin{tabular}{|c|c|c|c|}
\hline No & University & Waqf Administration Institutions & Established \\
\hline 1. & $\begin{array}{l}\text { Universiti Putra Malaysia } \\
\text { (UPM) }\end{array}$ & $\begin{array}{l}\text { Pusat Pengurusan Wakaf, Zakat dan } \\
\text { Endowment (WAZAN) }\end{array}$ & 2016 \\
\hline 2. & $\begin{array}{l}\text { Universiti Kebangsaan Malaysia } \\
\text { (UKM) }\end{array}$ & $\begin{array}{l}\text { Yayasan Canselor (Secretariat for } \\
\text { Dana Wakaf Ilmu) }\end{array}$ & 2016 \\
\hline 3. & $\begin{array}{l}\text { Universiti Islam Antarabangsa } \\
\text { Malaysia (UIAM) }\end{array}$ & IIUM Endowment Fund & 1999 \\
\hline 4. & Universiti Malaya (UM) & $\begin{array}{l}\text { UM Bursary's Fund Management \& } \\
\text { Credit Control Division }\end{array}$ & 2016 \\
\hline 5. & $\begin{array}{l}\text { University Sains Islam Malaysia } \\
\text { (USIM) }\end{array}$ & $\begin{array}{l}\text { Pusat Wakaf Dan Zakat/Centre for } \\
\text { Awqaf and Zakat }\end{array}$ & 2017 \\
\hline 6. & $\begin{array}{l}\text { Universiti Malaysia Kelantan } \\
\text { (UMK) }\end{array}$ & Pusat Islam UMK & 2016 \\
\hline 7. & $\begin{array}{l}\text { Universiti Teknologi Malaysia } \\
\text { (UTM) }\end{array}$ & Pejabat Wakaf UTM & 2017 \\
\hline 8 & $\begin{array}{l}\text { Universiti Malaysia } \\
\text { Pahang (UMP) }\end{array}$ & MyGift UMP & 2015 \\
\hline 9 & $\begin{array}{l}\text { Universiti Tun Hussein Onn } \\
\text { Malaysia (UTHM) }\end{array}$ & Pusat Endowmen dan Wakaf & 2017 \\
\hline 10 & $\begin{array}{l}\text { Universiti Malaysia } \\
\text { Sabah (UMS) }\end{array}$ & $\begin{array}{l}\text { Centre for Investment and } \\
\text { Endowment }(\mathrm{CIE}) / \text { Pusat Pelaburan } \\
\text { dan Endowment }\end{array}$ & 2017 \\
\hline 11 & $\begin{array}{l}\text { Universiti Pendidikan Sultan } \\
\text { Idris (UPSI) }\end{array}$ & Pusat Islam UPSI & $\mathrm{N} / \mathrm{A}$ \\
\hline 12 & Universiti Sains Malaysia (USM) & $\begin{array}{l}\text { Pejabat Zakat Waqaf \& Infaq } \\
\text { (ZAWAIN) }\end{array}$ & 2017 \\
\hline
\end{tabular}

\section{The Role of Resources to Contribute in Waqf Education Development}

Waqf can be a very effective mechanism for national economic development (Abdullahi, 2020). In fact, it has historically played an important role in this regard, and it still has the potential to do so in the present and future. Other than to the economic development, waqf will be equally relevant in the current drive to improve the society as well as giving an economic and social dynamism. Waqf's philosophy and spirit are extremely basic and essential for a strong society. In fact, the waqf institution can be used to mobilise voluntary donations from well-to-do Muslims to organise society. Meanwhile, specific to waqf for education, it can be channelled for building hostels, providing scholarships and allowances, and developing learning materials (Mujani et al., 2018).

Instead of being a vital institution as it truly played at the pre-modern era, waqf nowadays seems to be an impediment to the development in Muslim countries, including Malaysia. However, improving waqf practices in terms of management of resources, enhancing the flow of revenues including through investment of its liquid assets and efficient distribution are the key issues to achieve its objectives for the community development (Khalil et al., 2014). 
Therefore, it is important to firstly identify how resources can play their roles to contribute in waqf education development, specifically by looking into resource-based factors. This is done through the adaption from Research Based View (RBV) theory. The RBV is mainly related to organisational resources and capabilities that pose a competitive advantage and impact on organisational performance. With regards to RBV, previous study has highlighted among the intangible resources that can be counted to significantly contribute to the performance of the organisation which are trust, commitment, networking, as well as other factors that relatable to any criteria of RBV which are valuable, rare, imitability and substitutability (Barney et al., 2001; Barrutia \& Echebarria, 2015; Kamasak, 2015, 2017; Pee \& Kankanhalli, 2016).

\section{Findings \& Discussion}

Waqf can be a very effective mechanism for national economic development (Rana et al., 2020). Then, the implementation of endowment and waqf funds is essential and can be used as a continuous source of finance for an educational institution. Furthermore, waqf was not only performed and successfully brought the light to the Muslim world during these days, but it was also practised and successfully brought the light to the Muslim world throughout the early centuries of Islam. Similarly, waqf, with its distinct pillars, enables public institutions to provide better value and achieve higher levels of quality. However, the resources must firstly be adhered to ensure the development of waqf education can be sustained and continue to contribute to the development of quality education of society.

In this study, with regards to RBV, meanwhile the previous studies (Barney et al., 2001; Barrutia \& Echebarria, 2015; Kamasak, 2015, 2017; Pee \& Kankanhalli, 2016) were focused on the organisational perspective, this study focuses to the individual perspective in which the study proposed in Figure 1, that trust and commitment can positively influence the willingness of donor or waqif to contribute specifically to waqf education. It is because, an organisation needs to ensure the publics which will become a donor or waqif to have a trust toward the organisation who managed the waqf education fund. They need to ensure that the organisation is capable to develop the educational institution and contribute back to the society transparently. Then, the donors or waqif would like to put a commitment before they decide to willingly contribute to the waqf education fund.

Waqf can be a very effective mechanism for national economic development (Abdullahi, 2020). In fact, it has historically played an important role in this regard, and it still has the potential to do so in the present and future. Other than to the economic development, waqf will be equally relevant in the current drive to improve the society as well as giving an economic and social dynamism. Waqf's philosophy and spirit are extremely basic and essential for a strong society. In fact, the waqf institution can be used to mobilise voluntary donations from well-to-do Muslims to organise society. Meanwhile, specific to waqf for education, it can be channelled for building hostels, providing scholarships and allowances, and developing learning materials (Mujani et al., 2018). 


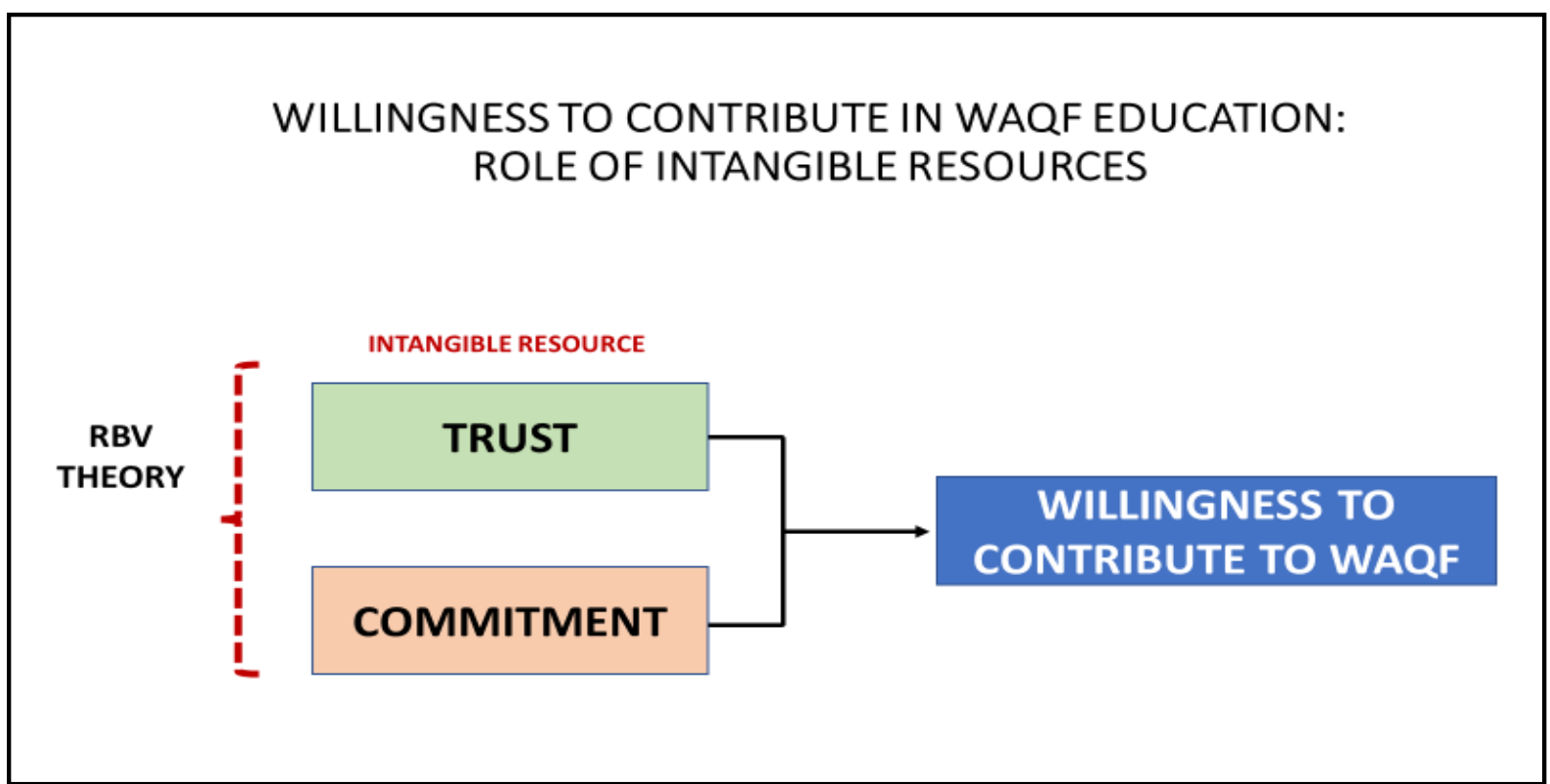

Figure 1. Proposed Conceptual Framework of the Study (Author's own)

Sources Adapted: Barney et al., 2001; Barney \& Arikan, 2005

\section{Conclusion \& Recommendation}

The establishment of waqf fund in the current globalised and economic downturn is viable to release the pressure of public universities as a consequence of budgeting slashed. It is because, the implementation of waqf funds is essential for an educational institution as a continuous source of finance to growth. Having waqf fund in the universities also opens the door to Muslim's philanthropist to donate their assets for the betterment of ummah. In the same way, waqf with its unique pillars, allows the public universities to deliver greater value and attain higher levels of quality.

Not to mention, in order to ensure the preservation of waqf in the university, all potential issues that could jeopardise the waqf fund should be avoided from the start. Thus, to ensure the preservation of waqf in the university, all the expected issues that might ruin the waqf fund should be circumvented from the initial stage, including to critically identify the resources that need to be adhered in order to ensure the waqf education development can be progressed effective and efficiently. Trust and commitment on the other hand, have become among the critical resources that contribute to the performance and growth of waqf education for a sustainable socio-economic growth.

\section{Corresponding Author}

Siti Sara Ibrahim

Universiti Teknologi MARA, Cawangan Negeri Sembilan, Kampus Rembau, Malaysia and Center for Islamic Philanthropy and Social Finance, Universiti Teknologi MARA, Cawangan Melaka, Malaysia

Email: saraibrahim@uitm.edu.my 


\section{References}

\section{Journal article}

Adnan, S. N. S. M., \& Valliappan, R. (2019). Communicating shared vision and leadership styles towards enhancing performance. International Journal of Productivity and Performance Management.

Ahmad, R., Albasri, S. H., Arsad, S., \& Said, R. (2018). A Critical Analysis of Zakat and Waqf in Sustaining the Development and Survival of Pondok Institution in Kedah, The 2nd Islamic Management Developmet Conference (IMDEC 2018).

Ali, N. A., \& Markom, R. (2020). The challenges in implementing cash waqf in Malaysia. Journal of Contempory Islamic Studies, 6(2).

Asni, F., Mahamud, M. A., \& Sulong, J. (2020). Socioeconomics and management of Muslim cemetery waqf using istibdal and GIS method in Penang state. Journal of Islamic Accounting and Business Research, 11(7), 1343-1362.

https://doi.org/10.1108/JIABR01-2019-0026

Bakar, R. (2018). Cash waqf for education: prospects and challenges. Journal of Emerging Economies and Islamic Research, 6(2), 1-4.

Bakar, R., Sakinah, W., Zaini, R., \& Sarmin, F. (2019). Corporate waqf university: a sustainability model. Journal of Emerging Economies and Islamic Research, 7(1), 24-36.

Barney, J., Wright, M., \& Ketchen Jr, D. J. (2001). The resource-based view of the firm: Ten years after 1991. Journal of management, 27(6), 625-641.

Barrutia, J. M., Echebarria, C., Paredes, M. R., Hartmann, P., \& Apaolaza, V. (2015). From Rio to Rio+ 20: twenty years of participatory, long term oriented and monitored local planning?. Journal of Cleaner Production, 106, 594-607.

Da Wan, C., Sirat, M., \& Razak, D. A. (2018). Education in Malaysia towards a developed nation.

Hasan, R., Hassan, M. K., \& Rashid, M. (2019). The Role of Waqf in Educational DevelopmentEvidence from Malaysia. Journal of Islamic Finance, 8(1), 001-007.

Ibrahim, H., Amir, A., \& Masron, T. A. (2013). Cash waqf: An innovative instrument for economic development. International Review of Social Sciences and Humanities, 6(1), $1-7$.

Ismail, M. H., \& Muamalah, F. P., bin Muhammad Som, H., Islam, A., Deni, M. I. M., \& binti Sulaiman, M. (2015). Model operasi wakaf pendidikan di malaysia. In International Conference on Cash Waqf 2015 (ICCW2015) (p. 217).

Kamasak, R. (2015). Determinants of innovation performance: A resource-based study. Procedia-Social and Behavioral Sciences, 195, 1330-1337.

Kamasak, R. (2017). The contribution of tangible and intangible resources, and capabilities to a firm's profitability and market performance. European Journal of Management and Business Economics.

Khalil, I. A., Ali, Y., \& Shaiban, M. (2014, December). Waqf fund management in Kuwait and Egypt: Can Malaysia learns from their experiences. In Proceeding of the International Conference on Masjid, Zakat and Waqf (IMAF 2014) (pp. 1-2).

Mahamood, S. M., Ab Rahman, A., \& Seman, A. C. (2018). Pembentukan Institusi Pengajian Tinggi Berteraskan Wakaf Di Malaysia: Cadangan Model Pelaksanaannya: The Establishment of a Waqf-Based Higher Educational Institution in Malaysia: Proposed Model for Implementation. Jurnal Syariah, 26(1), 1-22. 
Mujani, W. K., Taib, M. S., Rifin, M. K. I., \& Khalid, K. A. T. (2018). The History of the Development of Higher Education Waqf in Malaysia. International Journal of Civil Engineering and Technology, 9(3), 549-557.

Mujani, W. K., \& Yaakub, D. D. N. I. (2017). Waqf for higher education in Malaysia: Overview on challenges. European Journal of Multidisciplinary Studies, 2(5), 455-461.

Nurjannah, N., \& Abdullah, M. W. (2020). Cash Waqf: Economic Solution during the Covid-19 Pandemic. FITRAH: Jurnal Kajian Ilmu-ilmu Keislaman, 6(2), 223-242.

Pee, L. G., \& Kankanhalli, A. (2016). Interactions among factors influencing knowledge management in public-sector organizations: A resource-based view. Government Information Quarterly, 33(1), 188-199.

Rauf, M. B., \& Jabeen, M. R. (2019). The Role of Education Sector in the Development of Malaysia. Pakistan Journal of International Affairs, 2(1).

Rana, M. S., Rahman, M. K., Alam, M. R., \& Hoque, M. N. (2020). Waqf-Based Microfinance: An Alternative Solution to Poverty Reduction. Selangor Business Review, 5(1), 40-54.

Razak, N. A., Mazlan, M. N. H., Rentah, F., \& Malik, H. K. A. (2018). Realising the potential of implementation waqf in higher education institution: Case study in Malaysia. COMRAP 2018, 113.

Sari, M. D., Yusof, A. A., \& Ibrahim, A. (2018). Sinergi Wakaf dan Keusahawanan di University College Bestari. Jurnal Syariah, 26(1), 41-70.

Mahamood, S. M., Rahman, A. A. \& Seman, A. C. (2018). Pembentukan Institusi Pengajian Tinggi berteraskan Wakaf di Malaysia: Cadangan Model Pelaksanaannya. Jurnal Syariah.26(1), 1-22

Sukmana, R. (2020). Critical assessment of Islamic endowment funds (Waqf) literature: lesson for government and future directions. Heliyon, 6(10), e05074.

\section{Book}

Ahmad, A. U. F., \& Karim, M. F. (2019). Opportunities and challenges of waqf in Bangladesh: the way forward for socio-economic development. In Revitalization of Waqf for SocioEconomic Development, Volume I (pp. 193-212). Palgrave Macmillan, Cham.

Aziz, M. R. A., \& Johari, F. (2014). Waqf: Financing for Higher Education: Issues, Challenges and the Way Forward. USIM Publisher

Barney, J. B., \& Arikan, A. M. (2005). The resource-based view: origins and implications. The Blackwell handbook of strategic management, 123-182. 